\title{
Beneficial Role of MWCNTs and SNP on Growth, Physiological and Photosynthesis Performance of Barley under NaCl Stress
}

\author{
Afshin Karami $^{1}$, Ali Sepehri ${ }^{*}$ \\ ${ }^{1}$ Department of Agronomy and Plant Breeding, Faculty of Agriculture, Bu-Ali Sina University, Hamedan, \\ Iran. *Corresponding author: a_sepehri@basu.ac.ir
}

\begin{abstract}
MWCNTs (Multi-walled carbon nanotubes), as an important nanomaterial, enters the soil through various anthropogenic sources. Our understanding of MWCNTs effects on plant growth is still not complete and needs to be more studied. In this study, the possible effects of MWCNTs (500, 1000 and $\left.2000 \mathrm{mg} \mathrm{kg}^{-1}\right)$ and $100 \mu \mathrm{M}$ exogenous sodium nitroprusside (SNP, as NO donor) on growth, physiological and photosynthetic performance of barley plants under 100 and $200 \mathrm{mM} \mathrm{NaCl}$ stress were investigated in greenhouse conditions. The most of physiological and photosynthesis characteristics of barley seedling negatively impressed when the plants were grown in different concentrations of $\mathrm{NaCl}$. In the presence of SNP, $500 \mathrm{mg} \mathrm{kg}^{-1}$ dosage of MWCNTs significantly enhanced relative water content (RWC), chlorophyll content, photosynthesis parameters and growth indices. Also, MWCNTs-treated plants combined with $100 \mu \mathrm{M}$ SNP showed higher antioxidant enzyme activities such as superoxide dismutase (SOD), catalase (CAT), ascorbate peroxidase (APX) and lower malonyldialdehyde (MDA) and hydrogen peroxide $\left(\mathrm{H}_{2} \mathrm{O}_{2}\right)$ content under salinity stress. It is suggested that, MWCNTs in presence of SNP can greatly improve growth, as well as salt tolerance of barley plant by promoting water uptake, activities of antioxidant enzymes and photosynthesis performance.
\end{abstract}

Keywords: Antioxidant enzyme, growth indices, photosynthesis, salinity. 


\section{Introduction}

In recent years, nanomaterials (NMs) are commonly used in a wide range of different sciences like cosmetics, environmental health, biomedical sciences, health care, electronics, chemical industries, mechanics, energy science and etc. (Singh, 2017). Management of crop in agricultural is remarkably affected by nanomaterials (Taha et al., 2016). There is reliable evidence for various impacts of nanomaterials in plants which are dependent on the species, composition and their physiochemical properties (Khan et al., 2017).

Carbon nanotubes (CNTs) with molecular-scale tubes of graphitic carbon, is considered as one of the most produced NMs. Because of its incomparable nanostructures and amazing features, such as large specific surface area, high aspect ratio, high electrical conductivity and remarkable thermal stability, the CNTs is greatly used in different productions (Abdalla et al., 2015). As a whole, CNTs are categorized into single-walled carbon nanotubes (SWCNTs) and multi-walled carbon nanotubes (MWCNTs). The MWCNTs are more facile to be accessible than SWCNTs. They are the most important class of carbon nanomaterials with the highest production volumes and plentiful technical applications. Recently, there is an extensive interest in applying carbon nanotubes to crops for agricultural purpose. CNTs have huge potential to be applied as directed delivery systems for pesticides, fertilizer and other chemical compounds. There are many studies about the different impacts of carbon nanotubes in mammalian cells but unfortunately scant attention has focused on the effect of CNT in the agro sciences. Plants are an integral part of ecosystems; therefore, their interaction with CNT is unavoidable. Recently, it has been found that CNTs in the soil can affect performance of plants (Yuan et al. 2011; Giraldo et al. 2014). A few researches are available on the interactions between MWCNTs and crops under stressful condition (Hatami et al.,
2017; Martínez-Ballesta et al., 2016). Hence, the possible impacts of MWCNTs in the soil on crop growth under abiotic stress need to be discovered.

Salinity is one of the most important environmental stresses, which noticeably hinders crop productivity in many arid and semi-arid regions (Torbaghan et al., 2017). Low precipitation, high surface evaporation, poor cultural practices and irrigation with saline water are among the major contributors to the increasing salinity problems (Hussain et al., 2016). In general, a group of morphological, physiological and biochemical changes in the plant growth are caused by soil salinity. Excessive accumulation of $\mathrm{NaCl}$ has both osmotic (cell dehydration) and toxic (ion accumulation) effects for performance of plants. There is a lot of evidence that reactive oxygen species (ROS) are accumulated in plants exposed to high levels of salt which cause oxidative damage to biomolecules (Dong et al., 2015).

Nitric oxide (NO), as a reactive nitrogen species, is an important signaling molecule involved in the plant's antioxidant response against both biotic and abiotic stresses. NO has numerous functions in plant growth, development and defense responses in plants under stress conditions (Fatma et al., 2016). There are few researches which indicated that nitric oxide can change nanomaterials impacts on crops (Chen et al., 2015). Barley (Hordeum vulgare L.) is the cereal crop with the widest range of production areas in the world. It is known as a salt-tolerant crop and is suitable for growing in saline lands. Although barley is one of the most important crops in the world, the little attention has been paid to studying the impact of MWCNTs and NO on barley grown under salt stress. In this work, our aims were to determine the possible effects of MWCNTs in the presence of SNP (NO-donor) on some morphological, physiological and photosynthetic indices of barley seedling under different concentration of $\mathrm{NaCl}$. 


\section{Materials and Methods}

\subsection{Description of MWCNTS}

Multi-walled carbon nanotubes (purity: $>95 \%$, length: 10-30 um, OD: 20-30 nm, ID: 5-10 nm, ash: $<1.5 \mathrm{wt} \%$, surface area: $>110 \mathrm{~m}^{2} \mathrm{~g}^{-1}$, true density: $2.1{\mathrm{~g} . \mathrm{cm}^{-3}}^{-3}$ were supplied by Nanosany Co., Ltd., (Iran). The $x-$ ray diffraction pattern (A), thermo gravimetric analysis (B), Raman spectrometry (C), SEM and TEM image of MWCNTs (D) are shown in Figure 1.

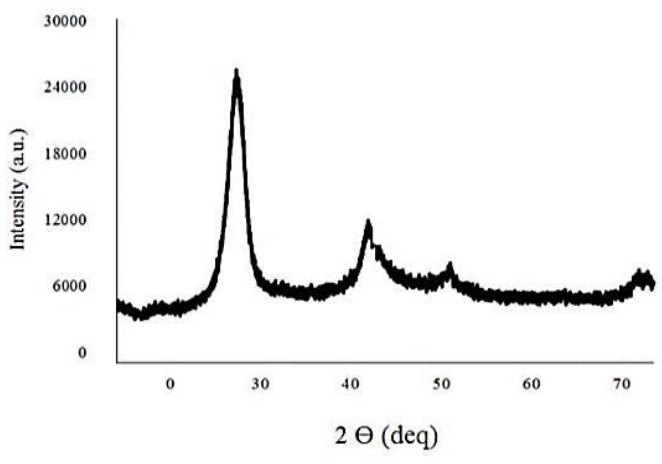

(A)

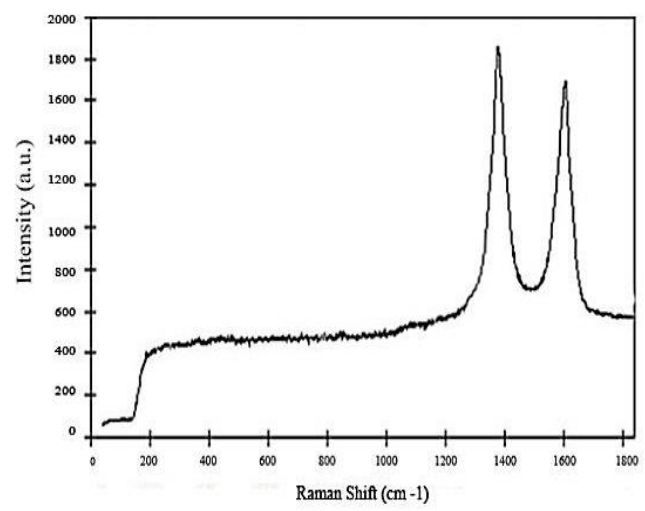

(C)

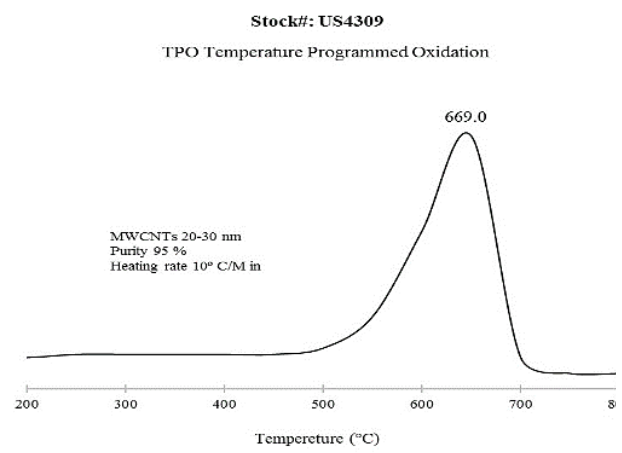

(B)

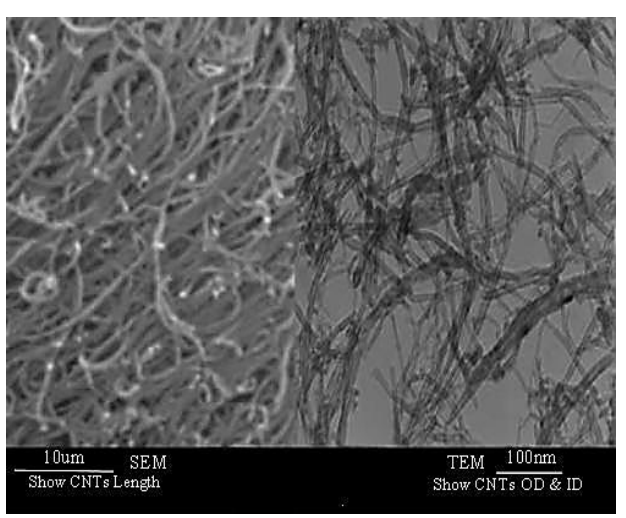

(D)

Figure 1. X-ray diffraction pattern of MWCNTs (A), Temperature programmed oxidation (TPO) pattern of MWCNTs (B), Raman Spectra of MWCNTs (C), Scanning electron microscope (SEM) and Transmission electron microscopy (TEM) images of MWCNTs (D). 


\subsection{Plant materials, treatments and growth condi-} tions

The experiment was set up in a factorial arrangement in a completely randomized design with three replications. The experimental treatments included four concentrations $\left(0,500,1000\right.$ and $\left.2000 \mathrm{mg} \mathrm{kg}^{-1}\right)$ of MWCNTs and two concentrations $(0$ and $100 \mu \mathrm{M})$ of sodium nitroprusside as NO donor under three concentrations of $\mathrm{NaCl}(0,100$ and $200 \mathrm{mM})$. The plants were grown in a greenhouse (light supplemented with fluorescent lamps was provided for $16 \mathrm{~h}$ per day with an irradiance of $250 \mu \mathrm{mol} \mathrm{m} \mathrm{m}^{-2} \mathrm{~s}^{-1}$, temperature of $28 / 18{ }^{\circ} \mathrm{C}$ day/night and $75 \%$ relative humidity) at the faculty of agriculture, Bu-Ali Sina University, Hamadan, Iran, in 2017. Twenty barley seeds (var. Afzal) were directly cultivated in pots $(14 \mathrm{~cm}$ diameter and $13 \mathrm{~cm}$ depth), containing $1.5 \mathrm{~kg}$ of soil (a clay loam soil with electric conductivity of 0.75 $\mathrm{dSm}^{-1}$ and $\mathrm{pH}$ of 7.1. The concentrations of total $\mathrm{N}$, $\mathrm{P}, \mathrm{K}, \mathrm{Fe}, \mathrm{Zn}, \mathrm{Cu}, \mathrm{Mn}$ and $\mathrm{Mg}$ were $0.15 \%, 9.2,220$, $10.5,0.9,0.75,12$ and $90 \mathrm{mg} \mathrm{kg}^{-1}$, respectively). The MWCNTs powder was added to the soil and mixed before seed cultivation. After plant growths and having them thinned, 12 plants remained in each pot and $\mathrm{NaCl}$ was added gradually with irrigation. SNP was applied as foliar spray seven days after completion of $\mathrm{NaCl}$ treatments. After 40 days of plant growths, we measured photosynthetic parameters and began to harvest plants for studying the morphological and physiological indices.

\subsection{Determination of root and shoot lengths}

The lengths of the roots and shoots of barley seedlings were measured with a rectilinear scale. Three plants of similar size from the population were used to determine the root and shoot lengths.

\subsection{Determination of relative water content $(R W C)$}

The relative water content was measured according to the method of Barrs and Weatherley (1962). A composite sample of leaf discs was taken and the fresh weight was measured, then they were put into distilled water for four hours in low-light intensity to determine the turgid weight. Water remaining on the surface of the plants was blotted with filter paper. After that, the slices were dried for 48 hours at $72{ }^{\circ} \mathrm{C}$ and the RWC was determined through the following equation: $\mathrm{RWC}=($ fresh weight - dry weight $) /$ (Turgid weight - dry weight) $\times 100 \%$.

\subsection{Determination of chlorophyll content}

Total chlorophylls content was extracted from fresh materials $(0.5 \mathrm{~g})$ with $80 \%$ acetone solution as described by Arnon (1975). The resulting homogenate was centrifuged at $3000 \mathrm{~g}$ for $15 \mathrm{~min}$ and the absorbance of the supernatant was recorded by spectrophotometer (Spekol 2000- Analytikjena) at 645 and 663 $\mathrm{nm}$. The total chlorophyll content was calculated by the following equation: Total Chl content $\left(\mathrm{mg} \mathrm{g}^{-1} \mathrm{FW}\right)$ $=\left(20.2 \times \mathrm{D}_{645}+8.02 \times \mathrm{D}_{663}\right) \times \mathrm{V} /(1000 \times \mathrm{W})$, where $\mathrm{A}_{645}$ and $\mathrm{A}_{663}$ are the absorbance values at 645 and 663 $\mathrm{nm}$ respectively, $\mathrm{V}=$ volume of $80 \%(\mathrm{v} / \mathrm{v})$ acetone $(\mathrm{ml})$ and $\mathrm{W}=$ fresh weight of sample $(\mathrm{g})$.

\subsection{Determination of photosynthetic indices}

Gas exchange parameters of barley leaves, including net photosynthesis rate $(\mathrm{Pn})$, stomatal conductance (gs) and transpiration rate (E), were measured using a portable photosynthesis system (Li-COR 6400; USA). The measurements were done on a sunny day at light saturating intensity; PAR; $1000 \mu \mathrm{mol} \mathrm{m} \mathrm{m}^{-2} \mathrm{~s}^{-1}$, chamber block temperature was 28 , the flow rate was 
kept at $800 \mathrm{mmol} \mathrm{s}^{-1}$ and $360 \mu \mathrm{molmol}^{-1}$ atmospheric $\mathrm{CO}^{2}$ concentrations.

\subsection{Determination of total soluble proteins}

The soluble leaf protein content was estimated according to the method of Bradford (1976) using bovine serum albumin (BSA) as standard. The total soluble proteins were estimated $0.5 \mathrm{~g}$ of leaf tissues were grounded with liquid nitrogen and then resuspended in extraction buffer containing $50 \mathrm{mM}$ Tricine-Tris, 1 $\mathrm{mM}$ ethylene diamine tetraacetic acid (EDTA), $1 \mathrm{mM}$ dithiothreitol, $1 \mathrm{mM}$ leupeptin, $1 \mathrm{mM}$ pepstatin, and $1 \mathrm{mM}$ phenylmethylsulfonyl fluoride, $\mathrm{pH}$ 7.4. After centrifugation at $12000 \times \mathrm{g}$ for $30 \mathrm{~min}$ at $4{ }^{\circ} \mathrm{C}$. The absorbance of supernatant was noted at $595 \mathrm{~nm}$ against a blank.

\subsection{Determination of antioxidant enzymes}

Fresh leaf tissues $(5 \mathrm{~g})$ were ground in liquid nitrogen and homogenized at $4{ }^{\circ} \mathrm{C}$ in $1 \mathrm{ml}$ of $100 \mathrm{mM}$ potassium phosphate buffer ( $\mathrm{pH}$ 7.8). The homogenate was centrifuged at 12,000 rpm for $30 \mathrm{~min}$ and the supernatant was collected for enzymes assays.

The activity of superoxide dismutase (EC 1.15.1.1) was estimated according to the method of Giannopolitis and Ries (1977). The reaction mixture contained $1 \mu \mathrm{M}$ riboflavin, of $12 \mathrm{mM}$ L-methionine, $0.1 \mathrm{mM}$ EDTA, $50 \mathrm{mM}$ sodium carbonate $\left(\mathrm{Na}_{2} \mathrm{CO}_{3}\right), 75 \mu \mathrm{M}$ nitroblue tetrazolium (NBT), $25 \mathrm{mM}$ sodium phosphate buffer ( $\mathrm{pH}$ 6.8) and crude enzyme extract with a final volume of $3 \mathrm{~mL}$. Superoxide dismutase (SOD) activity was assayed by measuring the ability of the enzyme extract to inhibit the photo reduction of nitro blue tetrazolium (NBT). Every step of the analysis was carried out in the dark. The mixture was illuminated for 15 min with a $100-W$ lamp. For each sample, the same reaction mixture without illumination was prepared as the control. The absorbance was read at $560 \mathrm{~nm}$ in the spectrophotometer against reaction solution (blank). One unit of SOD was defined as the amount of enzyme which caused a 50\% decrease in the SOD-inhibited NBT reduction. SOD activity is expressed in units per $\mathrm{mg}$ protein.

Catalase (EC 1.11.1.6) was determined using the method described by Aebi (1984) with minor modifications. It was measured in a reaction mixture of $3 \mathrm{ml}$ containing $50 \mathrm{mM}$ potassium phosphate buffer ( $\mathrm{pH}$ 7.8), $10 \mathrm{mM} \mathrm{H}_{2} \mathrm{O}_{2}$ and crude enzyme extract. The decrease in the absorbance at $240 \mathrm{~nm}$ was recorded for $3 \mathrm{~min}$. The reaction started by adding $\mathrm{H}_{2} \mathrm{O}_{2}$ and a decrease in absorbance was recorded at $240 \mathrm{~nm}$ for 1 min. The catalase (CAT) activity was calculated with an extinction coefficient $\left(39.4 \mathrm{mM}^{-1} \mathrm{~cm}^{-1}\right)$ and was expressed in units per mg protein.

The activity of ascorbate peroxidase (EC 1.11.1.11) was assayed according to the method of Nakano and Asada (1981). It was measured in a reaction mixture of $3 \mathrm{ml}$ containing $50 \mathrm{mM}$ potassium phosphate buffer ( $\mathrm{pH}$ 7.0), $0.1 \mathrm{mM}$ EDTA- $\mathrm{Na}_{2}, 0.5 \mathrm{mM}$ ascorbic acid, $0.1 \mathrm{mM} \mathrm{H}_{2} \mathrm{O}_{2}$ and crude enzyme extract. The initial rate of the reaction using the extinction coefficient of ascorbate $\left(\varepsilon=2.8 \mathrm{mM}^{-1} \mathrm{~cm}^{-1}\right)$ at $290 \mathrm{~nm}$.

\subsection{Determination of proline contents}

Proline contents in leaf tissues were measured by the Bates et al. (1973) method. Leaf samples (0.5 g) were homogenized with $3 \%$ sulfosalicylic acid and then centrifuged at 10,000 rpm. Two $\mathrm{ml}$ of the supernatant was mixed with $2 \mathrm{ml}$ of ninhydrin reagent and the same volume of glacial acetic. The mentioned mixture was placed in a water bath for at $100{ }^{\circ} \mathrm{C}$ for $1 \mathrm{~h}$. After cooling the reaction mixture, toluene was added and the absorbance of toluene phase was read at $520 \mathrm{~nm}$ with a spectrophotometer. Appropriate proline standards were included in the calculation of proline in the samples. 


\subsection{Determination of malonyldialdehyde (MDA) content}

The concentration of MDA (lipid peroxidation) was determined based on the method of Heath and Packer (1968). Briefly, fresh leaves (1 g) were grounded in $3 \mathrm{ml}$ of $0.1 \%(\mathrm{w} / \mathrm{v})$ trichloroacetic acid solution and centrifuged at $12,000 \mathrm{~g}$ for $20 \mathrm{~min}$. The supernatant (3 $\mathrm{mL}$ ) was mixed with an equal volume of $0.5 \%(\mathrm{~W} / \mathrm{V})$ thiobarbituric acid (TBA). The mixture was incubated at $95{ }^{\circ} \mathrm{C}$ for $30 \mathrm{~min}$ and the reaction was stopped by placing ice bath and then centrifuged at $12000 \mathrm{~g}$ for $10 \mathrm{~min}$. The level of thiobarbituric acid-reactive substances (TBARS) was detected as specific absorbance at $532 \mathrm{~nm}$ by subtracting the non-specific absorbance at $600 \mathrm{~nm}$ and calculated using an extinction coefficient of $155 \mathrm{mM}^{-1} \mathrm{~cm}^{-1}$. The MDA content was computed based on its extinction coefficient of $155 \mathrm{mM}^{-1}$ $\mathrm{cm}^{-1}$ and expressed $\mathrm{nmol} \mathrm{g}{ }^{-1} \mathrm{FW}$.

\subsection{Determination of hydrogen peroxide $\left(\mathrm{H}_{2} \mathrm{O}_{2}\right)$}

The $\mathrm{H}_{2} \mathrm{O}_{2}$ content was determined according to Loreto and Velikiva (2001). Briefly, leaf samples (0.5 g) were grounded in an ice bath with $5 \mathrm{~mL}$ of $0.1 \%(\mathrm{w} / \mathrm{v})$ trichloroacetic acid (TCA) and centrifuged at 10,000 rpm for $4 \mathrm{~min}$. Next, $0.5 \mathrm{~mL}$ of the supernatant was added to $0.5 \mathrm{~mL} 10 \mathrm{mM}$ potassium phosphate buffer ( $\mathrm{pH} 7.0)$ and $1 \mathrm{~mL} 1 \mathrm{M} \mathrm{KI}$. Finally, the absorbency of the supernatant was read at $390 \mathrm{~nm}$. The $\mathrm{H}_{2} \mathrm{O}_{2}$ content was calculated by comparison with a standard calibration curve prepared using different concentrations of $\mathrm{H}_{2} \mathrm{O}_{2}$.

\subsection{Determination of $\mathrm{Na}^{+}$and $\mathrm{K}^{+}$concentration}

$\mathrm{Na}^{+}$and $\mathrm{K}^{+}$measurements were conducted according toEnders and Lehmann (2012) with minor modifications.
Barley leaves transferred to the oven at $72{ }^{\circ} \mathrm{C}$ for $48 \mathrm{~h}$ and then the dried samples were crushed into powder using mortar and pestle. Following this, 0.2 $\mathrm{g}$ of plant material was added to $4 \mathrm{~mL}$ nitric acid. Samples were placed for $60 \mathrm{~min}$ in water bath at 65 ${ }^{\circ} \mathrm{C}$ and then heated for $90 \mathrm{~min}$ at $100{ }^{\circ} \mathrm{C}$. Next tubes were allowed to cool before adding $0.2 \mathrm{~mL} \mathrm{H}_{2} \mathrm{O}_{2}$. Finally, $\mathrm{Na}^{+}$and $\mathrm{K}^{+}$concentrations were determined by using flame photometer.

\subsection{Statistical data analyses}

All data presented are the mean values of three independent sets of experiments ( \pm SD). The statistical analyses were carried out using SAS 9.3 software. Significant differences among the treatment means were compared by the least significant difference (LSD) test at $\mathrm{P} \leq 0.05$ level of significance.

\section{Results}

\subsection{Root and shoot lengths}

The effects of $\mathrm{NaCl}$, MWCNTs and SNP on growth attributes were evaluated by examining root and shoot lengths of barley plants (Figure. 2A, 2B and Table 1). Both the root and shoot lengths of seedlings decreased under salinity stress. The MWCNTs led to significantly promoting in the root and shoot lengths under both stress and non-stress conditions. Although all of MWCNTs dosages promoted barley shoot lengths, the maximum root length was recorded at $500 \mathrm{mg} \mathrm{kg}^{-1} \mathrm{MWCNTs}$ under all salinity levels (Figure 2A). MWCNTs at $500 \mathrm{mg} \mathrm{kg}^{-1}$ improved root length by about 26.9 and $34.1 \%$ respectively under 100 and $200 \mathrm{mM} \mathrm{NaCl}$. 
A

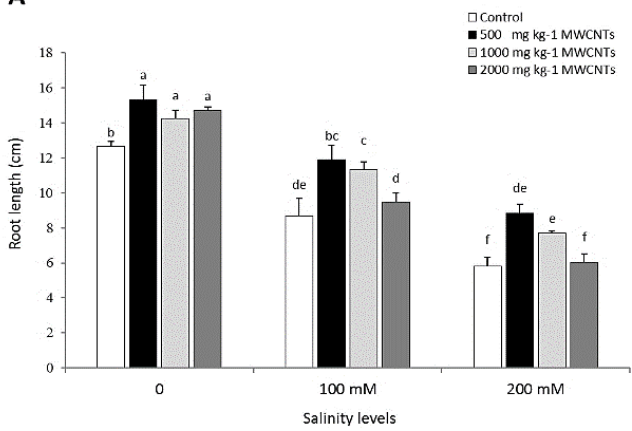

C

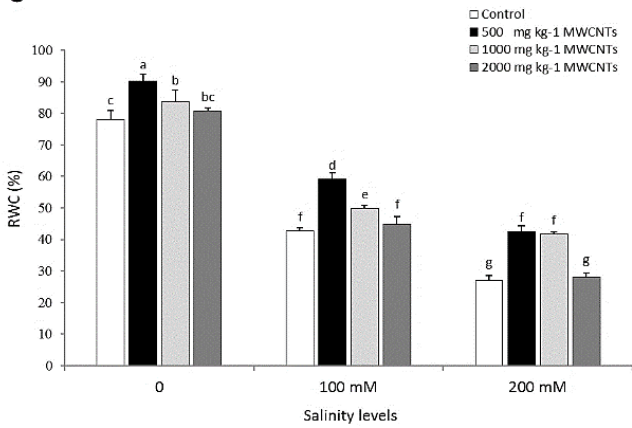

B

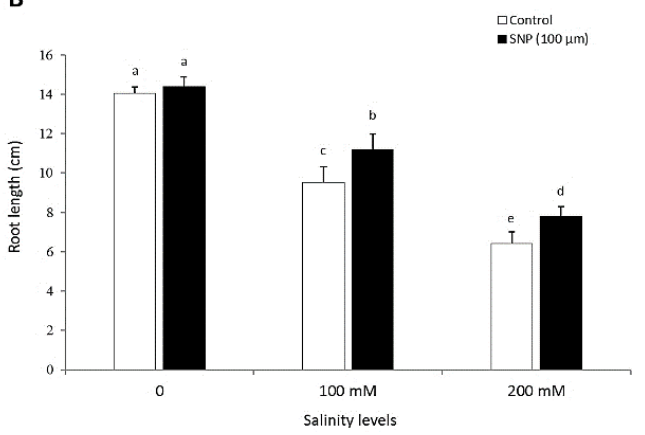

D

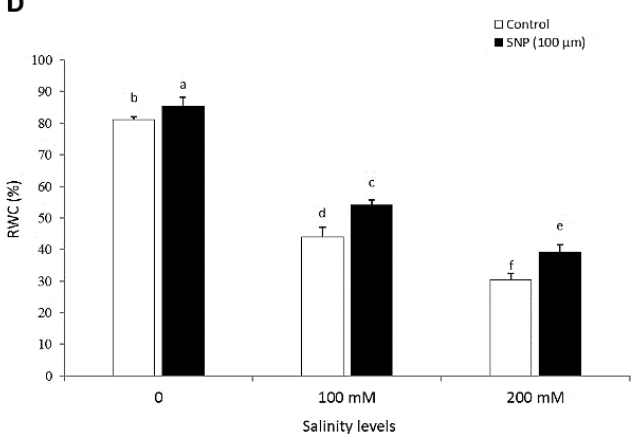

Figure 2. Effects of MWCNTs and salinity levels on root length (A) and RWC (C) of barley. Effects of NO donor (SNP) and salinity levels on root length (B) and RWC (D) of barley. Values with the same letter did not significantly differ at $\mathrm{P} \leq 0.05$ levels based on LSD

Similarly, shoot length was positively impressed by MWCNTs (Table 1). Application of NO donor (SNP) enhanced root and shoot lengths over control, but the alleviatory effects of SNP under salinity were more efficient than non-stress condition (Table 1).
SNP intensified the impact of MWCNTs on shoot length of barley. As shown in Table 1, the highest shoot length was obtained at $500 \mathrm{mg} \mathrm{kg}^{-1}+\mathrm{SNP}$ under 100 and $200 \mathrm{mM} \mathrm{NaCl}$. 
Table 1. Shoot Length (SL), photosynthetic rate (Pn), activity of SOD, MDA, $\mathrm{H}_{2} \mathrm{O}_{2}$ and total soluble protein content (TSP) of barley plants in response to MWCNTs and SNP under various salinity levels

\begin{tabular}{|c|c|c|c|c|c|c|c|c|}
\hline & Treatments & & & & & & & \\
\hline $\begin{array}{c}\text { Salinity } \\
(\mathrm{mM})\end{array}$ & $\begin{array}{c}\text { MWCNTs } \\
\left(\mathrm{mg} \mathrm{kg}^{-1}\right)\end{array}$ & $\begin{array}{l}\text { SNP } \\
(\mu \mathrm{M})\end{array}$ & $\begin{array}{l}\mathrm{SL} \\
(\mathrm{cm})\end{array}$ & $\left(\mu \mathrm{mol} \mathrm{m}{ }^{-2} \mathrm{~s}^{-1}\right)$ & (U mg-1 pro) & $\left(\mathrm{nmol} \mathrm{g}{ }^{-1} \mathrm{FW}\right)$ & $\left(\mu \mathrm{mol} \mathrm{g}{ }^{-1} \mathrm{FW}\right)$ & $\left(\mathrm{mg} \mathrm{g}^{-1} \mathrm{FW}\right)$ \\
\hline \multirow{8}{*}{0} & \multirow{2}{*}{0} & 0 & $28.10 \pm 0.90$ & $19.28 \pm 0.56$ & $6.17 \pm 1.09$ & $8.90 \pm 0.50$ & $0.94 \pm 0.03$ & $43.90 \pm 0.49$ \\
\hline & & 100 & $29.00 \pm 0.70$ & $20.48 \pm 1.11$ & $6.90 \pm 0.89$ & $8.10 \pm 0.56$ & $0.80 \pm 0.05$ & $47.00 \pm 1.74$ \\
\hline & \multirow{2}{*}{500} & 0 & $32.59 \pm 1.00$ & $23.18 \pm 0.95$ & $8.41 \pm 0.76$ & $6.61 \pm 0.70$ & $0.77 \pm 0.04$ & $57.00 \pm 1.50$ \\
\hline & & 100 & $33.62 \pm 0.33$ & $23.68 \pm 1.22$ & $8.90 \pm 0.23$ & $6.00 \pm 0.84$ & $0.75 \pm 0.10$ & $59.00 \pm 1.55$ \\
\hline & \multirow{2}{*}{1000} & 0 & $32.05 \pm 0.45$ & $22.48 \pm 0.98$ & $7.51 \pm 0.20$ & $7.35 \pm 0.56$ & $0.65 \pm 0.11$ & $55.60 \pm 1.80$ \\
\hline & & 100 & $32.45 \pm 1.02$ & $22.48 \pm 0.68$ & $8.20 \pm 1.00$ & $7.11 \pm 0.45$ & $0.60 \pm 0.02$ & $55.60 \pm 1.36$ \\
\hline & \multirow{2}{*}{2000} & 0 & $31.00 \pm 0.71$ & $20.53 \pm 1.11$ & $7.04 \pm 0.70$ & $7.80 \pm 0.63$ & $0.79 \pm 0.03$ & $51.70 \pm 1.74$ \\
\hline & & 100 & $31.60 \pm 0.92$ & $21.51 \pm 0.75$ & $7.27 \pm 0.65$ & $7.58 \pm 0.56$ & $0.70 \pm 0.10$ & $53.65 \pm 1.69$ \\
\hline \multirow{8}{*}{100} & \multirow{2}{*}{0} & 0 & $17.00 \pm 0.85$ & $11.39 \pm 0.87$ & $9.90 \pm 0.39$ & $19.66 \pm 0.78$ & $1.55 \pm 0.11$ & $24.80 \pm 2.10$ \\
\hline & & 100 & $22.01 \pm 0.55$ & $17.23 \pm 1.00$ & $12.69 \pm 0.42$ & $17.57 \pm 0.69$ & $1.25 \pm 0.09$ & $36.51 \pm 2.00$ \\
\hline & \multirow{2}{*}{500} & 0 & $25.61 \pm 0.43$ & $18.18 \pm 0.69$ & $14.07 \pm 0.54$ & $15.33 \pm 0.48$ & $1.34 \pm 0.05$ & $40.40 \pm 0.90$ \\
\hline & & 100 & $28.53 \pm 0.58$ & $20.48 \pm 0.89$ & $18.20 \pm 0.88$ & $12.52 \pm 0.16$ & $1.56 \pm 0.03$ & $45.12 \pm 1.25$ \\
\hline & \multirow{2}{*}{1000} & 0 & $20.06 \pm 0.52$ & $14.29 \pm 0.70$ & $12.19 \pm 1.00$ & $14.64 \pm 0.23$ & $1.41 \pm 0.06$ & $32.60 \pm 1.36$ \\
\hline & & 100 & $24.30 \pm 1.00$ & $18.18 \pm 1.00$ & $16.00 \pm 0.77$ & $13.89 \pm 0.22$ & $1.14 \pm 0.04$ & $40.40 \pm 1.51$ \\
\hline & \multirow{2}{*}{2000} & 0 & $17.42 \pm 0.88$ & $12.34 \pm 0.65$ & $11.26 \pm 0.35$ & $18.07 \pm 0.19$ & $1.45 \pm 0.06$ & $28.71 \pm 1.40$ \\
\hline & & 100 & $18.87 \pm 0.74$ & $13.12 \pm 1.46$ & $12.00 \pm 0.54$ & $14.83 \pm 0.62$ & $1.36 \pm 0.07$ & $30.26 \pm 1.22$ \\
\hline \multirow{8}{*}{200} & \multirow{2}{*}{0} & 0 & $12.20 \pm 0.25$ & $9.99 \pm 1.33$ & $18.10 \pm 0.60$ & $26.90 \pm 0.54$ & $2.55 \pm 0.03$ & $20.00 \pm 1.09$ \\
\hline & & 100 & $15.40 \pm 1.00$ & $12.49 \pm 1.11$ & $21.90 \pm 0.44$ & $21.62 \pm 0.39$ & $2.35 \pm 0.04$ & $25.10 \pm 1.20$ \\
\hline & \multirow{2}{*}{500} & 0 & $15.55 \pm 0.62$ & $12.49 \pm 0.98$ & $24.00 \pm 0.39$ & $19.69 \pm 0.19$ & $2.35 \pm 0.06$ & $25.00 \pm 1.24$ \\
\hline & & 100 & $22.54 \pm 0.71$ & $17.30 \pm 1.00$ & $25.02 \pm 0.56$ & $17.87 \pm 0.26$ & $1.97 \pm 0.02$ & $35.50 \pm 1.32$ \\
\hline & \multirow{2}{*}{1000} & 0 & $17.53 \pm 0.44$ & $13.56 \pm 0.89$ & $20.92 \pm 1.02$ & $25.24 \pm 0.44$ & $2.15 \pm 0.03$ & $27.14 \pm 1.47$ \\
\hline & & 100 & $20.04 \pm 0.92$ & $15.68 \pm 0.64$ & $23.28 \pm 1.00$ & $20.21 \pm 0.51$ & $1.73 \pm 0.06$ & $32.09 \pm 1.25$ \\
\hline & \multirow{2}{*}{2000} & 0 & $14.00 \pm 0.28$ & $10.09 \pm 0.56$ & $18.00 \pm 1.00$ & $26.03 \pm 0.30$ & $2.35 \pm 0.04$ & $16.00 \pm 1.78$ \\
\hline & & 100 & $15.05 \pm 0.62$ & $11.99 \pm 0.49$ & $20.11 \pm 0.82$ & $23.65 \pm 0.19$ & $2.21 \pm 0.02$ & $20.00 \pm 2.00$ \\
\hline & LSD & & 2.16 & 2.07 & 1.50 & 1.83 & 0.21 & 4.24 \\
\hline
\end{tabular}

Values are the means of three independent replicates $\pm \mathrm{SE}$; means are significantly different at $\mathrm{P} \leq 0.05$ according to the least significant difference (LSD) . 


\subsection{Relative water contents}

Analysis of the data showed that $\mathrm{NaCl}$ stress caused a significant decrease of relative water contents indices (Figure 2C). $\mathrm{NaCl}$ at 100 and $200 \mathrm{mM}$ reduced RWC 45.2 and $65.2 \%$ respectively compared to control plants. RWC of barley leaves improved at all level of MWCNTs concentrations under stress and non-stress conditions (Figure 2C). MWCNTs at 500, 1000 and $2000 \mathrm{mg} \mathrm{kg}^{-1}$ enhanced RWC by about $36.2,35$ and
$3.1 \%$ respectively under $200 \mathrm{mM} \mathrm{NaCl}$ level (Figure $2 \mathrm{C})$. Also, application of SNP significantly increased the RWC by 18.6 and $22.2 \%$ under 100 and $200 \mathrm{mM}$ salinity in the leaf tissues (Figure 2D). However, with the supply of $100 \mu \mathrm{m}$ SNP to the plants the positive impact of MWCNTs on the RWC of leaves were obviously increased (Table 2). Employing MWCNTs at $500 \mathrm{mg} \mathrm{kg}^{-1}$ with $100 \mu \mathrm{m} \mathrm{SNP}$ increased RWC by $12.02 \%$ in comparison with corresponding treatments of MWCNTs (Table 2).

Table 2. Relative water content (RWC), Stomatal conductance (gs), activity of CAT, APX and proline content of barley plants in response to MWCNTs and SNP.

\begin{tabular}{|c|c|c|c|c|c|c|}
\hline \multicolumn{2}{|c|}{ Treatments } & \multirow[b]{2}{*}{$\begin{array}{l}\text { RWC } \\
(\%)\end{array}$} & \multirow[b]{2}{*}{$\begin{array}{c}\text { gs } \\
\left(\mathrm{mmol} \mathrm{m} \mathrm{m}^{-2} \mathrm{~s}^{-1}\right)\end{array}$} & \multirow[b]{2}{*}{$\begin{array}{c}\text { CAT } \\
\left(\mathrm{U} \mathrm{mg}^{-1} \text { pro }\right)\end{array}$} & \multirow[b]{2}{*}{$\begin{array}{c}\mathrm{APX} \\
\left(\mathrm{U} \mathrm{mg}^{-1} \text { pro }\right)\end{array}$} & \multirow[b]{2}{*}{$\begin{array}{c}\text { Proline } \\
\left(\mathrm{mg} \mathrm{g}^{-1} \mathrm{FW}\right)\end{array}$} \\
\hline $\begin{array}{l}\text { MWCNTs } \\
\left(\mathrm{mg} \mathrm{kg}^{-1}\right)\end{array}$ & $\begin{array}{l}\text { SNP } \\
(\mu \mathrm{M})\end{array}$ & & & & & \\
\hline \multirow{2}{*}{0} & 0 & $43.30 \pm 0.79$ & $179.10 \pm 4.30$ & $0.84 \pm 3.20$ & $1.35 \pm 0.05$ & $190.46 \pm 0.06$ \\
\hline & 100 & $55.13 \pm 0.88$ & $217.90 \pm 5.12$ & $1.01 \pm 4.10$ & $1.66 \pm 0.03$ & $240.79 \pm 0.14$ \\
\hline \multirow{2}{*}{500} & 0 & $59.82 \pm 0.98$ & $221.70 \pm 6.20$ & $1.2 \pm 3.65$ & $1.73 \pm 0.04$ & $247.08 \pm 0.12$ \\
\hline & 100 & $68.00 \pm 1.20$ & $264.00 \pm 4.85$ & $1.43 \pm 4.60$ & $2.05 \pm 0.04$ & $286.56 \pm 0.10$ \\
\hline \multirow{2}{*}{1000} & 0 & $55.78 \pm 1.22$ & $221.71 \pm 6.98$ & $1.19 \pm 3.85$ & $1.70 \pm 0.03$ & $237.77 \pm 0.09$ \\
\hline & 100 & $61.03 \pm 1.10$ & $235.70 \pm 7.12$ & $1.2 \pm 3.71$ & $1.81 \pm 0.08$ & $262.57 \pm 0.08$ \\
\hline \multirow{2}{*}{2000} & 0 & $48.43 \pm 0.65$ & $195.30 \pm 4.60$ & $0.98 \pm 2.90$ & $1.49 \pm 0.06$ & $199.79 \pm 0.08$ \\
\hline & 100 & $53.87 \pm 1.18$ & $209.22 \pm 5.23$ & $1.09 \pm 5.00$ & $1.58 \pm 0.05$ & $225.76 \pm 0.19$ \\
\hline LSD & & 3.79 & 16.72 & 0.07 & 0.13 & 12.96 \\
\hline
\end{tabular}

Values are the means of three independent replicates $\pm \mathrm{SE}$; means are significantly different at $\mathrm{P} \leq 0.05$ according to the least significant difference (LSD). 


\subsection{Total chlorophyll}

Total chlorophyll content in intact plants was reduced strongly by $\mathrm{NaCl}$ treatment (Figure $3 \mathrm{~A}$ ). The most expressive reduction was observed under $200 \mathrm{mM}$ $\mathrm{NaCl}$. Also, statistically significant increase in total chlorophyll content was observed in plants treated with MWCNTs under $\mathrm{NaCl}$ levels. According to
Figure $3 \mathrm{~A}$, the highest total chlorophyll content was achieved at $500 \mathrm{mg} \mathrm{kg}^{-1}$ MWCNTs under $\mathrm{NaCl}$ stress. Moreover, foliar spray of SNP promoted total chlorophyll content of barley leaves compared to the control plants, under $\mathrm{NaCl}$ levels (Figure 3B). Exogenous application of NO in the form of SNP increased total chlorophyll content by about 15.2 and $26.2 \%$ under 100 and $200 \mathrm{mM} \mathrm{NaCl}$ levels (Figure 3B).
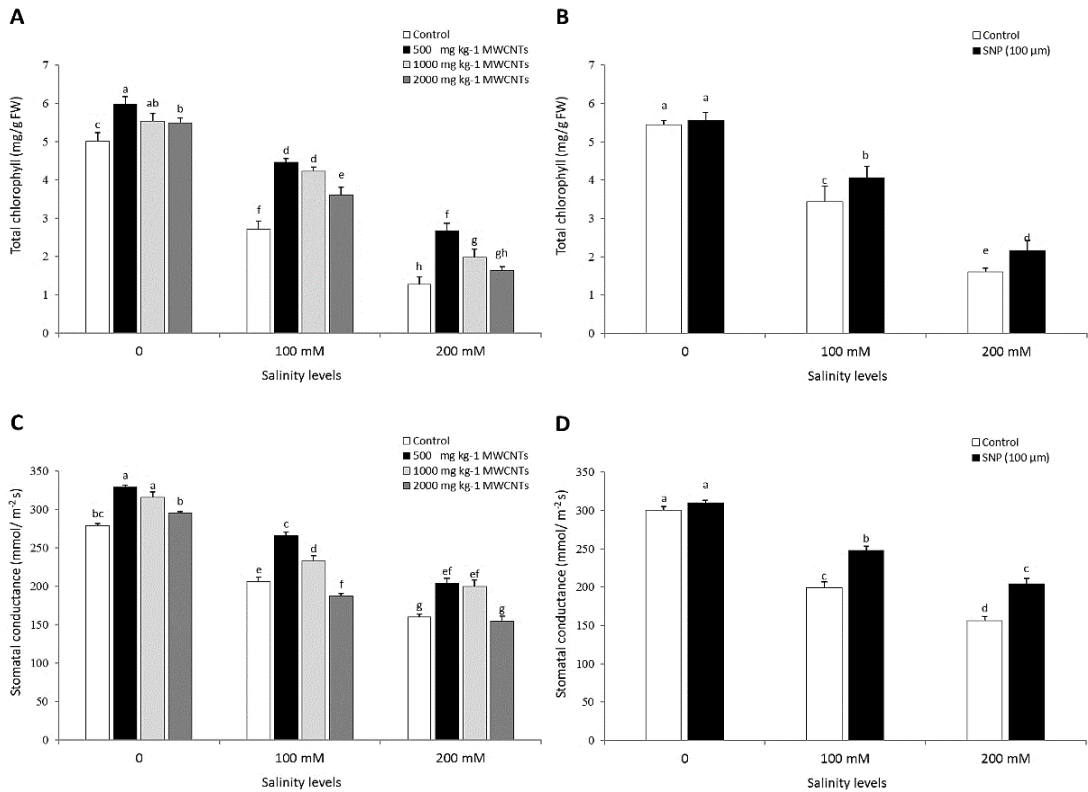

D
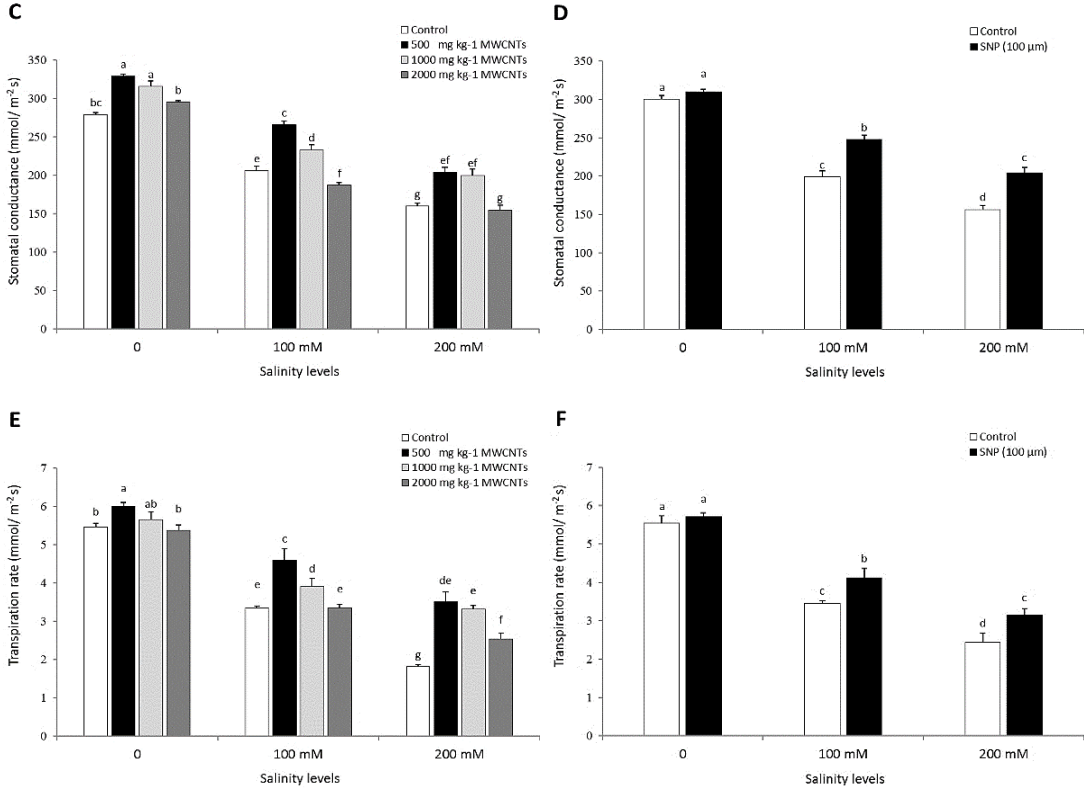

Figure 3. Effects of MWCNTs and salinity levels on total chlorophyll (A), stomatal conductance (C) and transpiration rate (E) of barley. Effects of NO donor (SNP) and salinity levels on total chlorophyll (B), stomatal conductance (D) and transpiration rate (F) of barley. Values with the same letter did not significantly differ at $\mathrm{P}$ $\leq 0.05$ levels based on LSD test. 


\subsection{Photosynthesis indices}

The net photosynthetic rate (Pn), stomatal conductance (gs) and transpiration (E) decreased gradually with the increase of $\mathrm{NaCl}$ concentrations (Table 1 and Figure $3 \mathrm{C}, 3 \mathrm{E}) . \mathrm{NaCl}$ at $200 \mathrm{mM}$ reduced $\mathrm{Pn}$, gs and E by about $48.1,42.5$ and $66.8 \%$ respectively compared to the control. Supplementing the MWCNTs-treated plants with SNP resulted significantly increasing of net photosynthetic rates (Table 1). The maximum net photosynthetic rate was achieved in $500 \mathrm{mg} \mathrm{kg}^{-1} \mathrm{MW}$ CNTs $+100 \mu \mathrm{m}$ SNP compared to other treatments (Table 1). The gs and E followed the similar pattern with Pn and supply of MWCNTs boosted the stomatal conductance and transpiration of barley plants (Figure $3 \mathrm{C}$ and $3 \mathrm{E}$ ). Moreover, a positive response to supply of SNP was recorded for gs and E parameters which were more efficient under salinity stress than the nonstress condition (Figure 3D and 3F). The gs and E of plants maintained at $200 \mathrm{mM} \mathrm{NaCl}$ level were 160.70 and 1.81, which slightly increased to 204.55 and 3.51 $\mathrm{mmol} \mathrm{m} \mathrm{m}^{-2} \mathrm{~s}^{-1}$ after application of SNP (Figure 3D and $3 F)$. In addition, SNP intensified the favorable effects of MWCNTs on stomatal conductance of barley. Referring to Table 2, the supply of SNP with MWCNTs (500 $\mathrm{mg} \mathrm{kg}^{-1}$ ) enhanced gs by about $13.77 \%$ over corresponding treatments of MWCNTs.

\subsection{Total soluble proteins (TSP)}

$\mathrm{NaCl}$ stress resulted in remarkable lower total soluble proteins content when compared with the control (Table 1). Exposing plants to $\mathrm{NaCl}$ levels caused a decrease of 43.5 and $54.4 \%$ in TPS respectively under 100 and $200 \mathrm{mM} \mathrm{NaCl}$. As shown in Table 1, total soluble proteins content was positively impressed by MWCNTs and SNP under both stress and non-stress conditions. The highest total soluble proteins content was recorded at MWCNTs $\left(500 \mathrm{mg} \mathrm{kg}^{-1}\right)+\operatorname{SNP}(100$ $\mu \mathrm{m})$ compared with other treatments. According to Table 1, MWCNTs at $500 \mathrm{mg} \mathrm{kg}^{-1}+$ SNP enhanced TSP by about 45.03 and $43.66 \%$ under 100 and 200 $\mathrm{mM} \mathrm{NaCl}$ stress.

\subsection{SOD, CAT and APX}

The results revealed significant impacts of the salinity, MWCNTs, SNP and their interaction on antioxidant enzyme activities of barley plants (Table 1 and Figure $4 \mathrm{~A}, 4 \mathrm{C}$ ). With the increase of $\mathrm{NaCl}$ concentration, the activities of SOD, CAT and APX were significantly increased compared with those in the absence of salt (Table 1 and Figure 4A, 4C). SOD activity sharply boosted followed by plants exposure to MWCNTs (especially at $500 \mathrm{mg} \mathrm{kg}^{-1}$ ) and SNP in combined use (Table 1). Mentioned treatment promoted SOD activity by about 45.06 and $27.65 \%$ under 100 and $200 \mathrm{mM}$ $\mathrm{NaCl}$. CAT and APX activities followed the similar pattern with SOD and supply of MWCNTs boosted the activities of APX and CAT (Figure 4A and 4C). The highest activities of CAT and APX were observed at $500 \mathrm{mg} \mathrm{kg}^{-1}$ MWCNTs. Similarly, plants exposed to SNP resulted in an increase of CAT and APX activities (Figure 4B and 4D). Application of SNP increased CAT and APX activities by 10.08 and $10.34 \%$ under $200 \mathrm{mM} \mathrm{NaCl}$ level. Furthermore, using SNP amplified the positive impacts of MWCNTs on CAT and APX activities compared with corresponding treatments of MWCNTs or untreated plants (Table 2). 
A

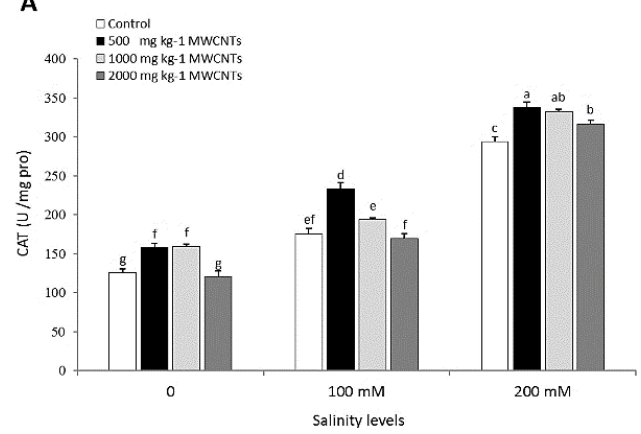

C

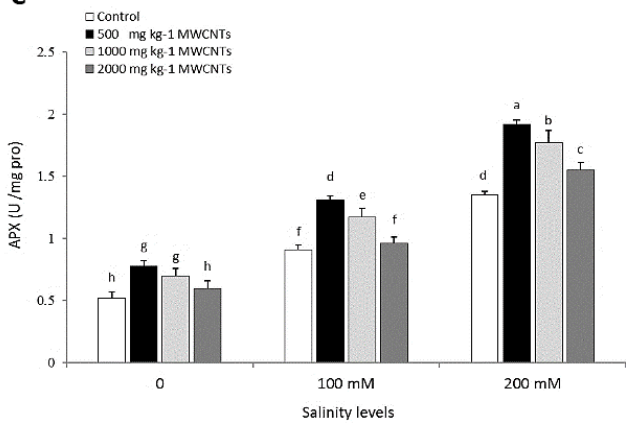

E

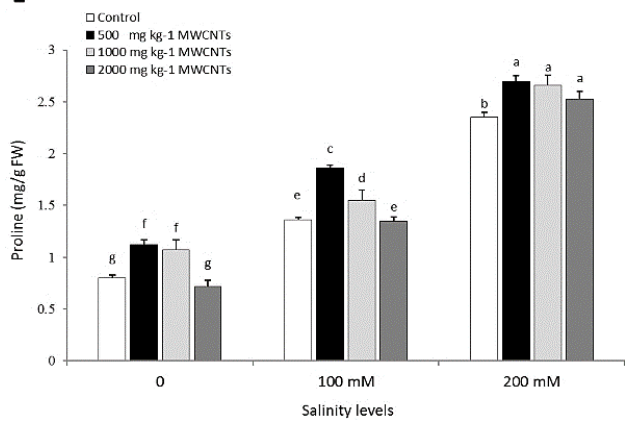

B

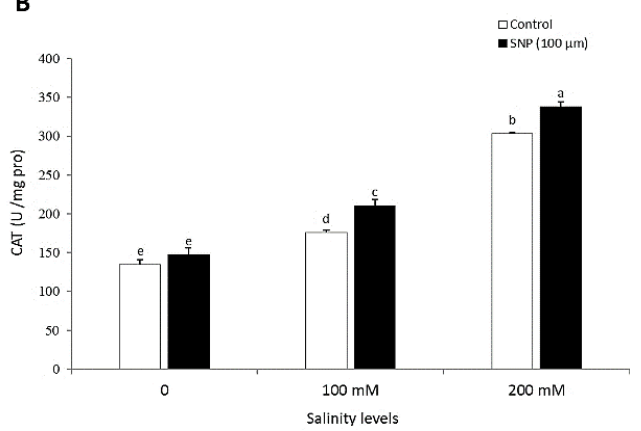

D

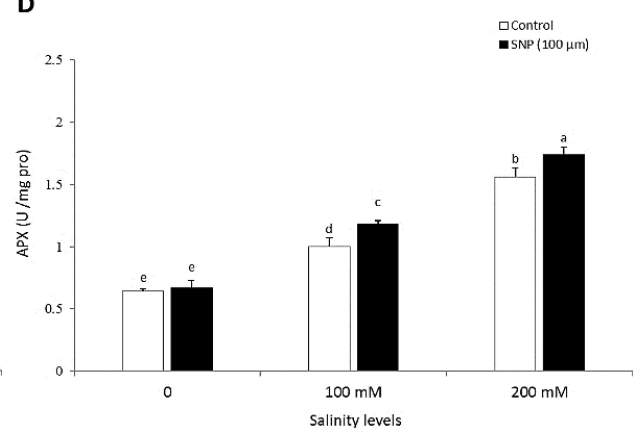

$\mathbf{F}$

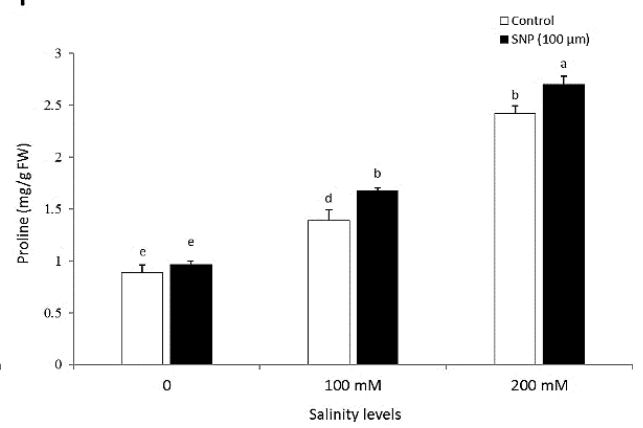

Figure 4. Effects of MWCNTs and salinity levels on the activity of CAT (A), APX (C) and proline content (E) of barley. Effects of NO donor (SNP) and salinity levels on the activity of CAT (B), APX (D) and proline content (F) of barley. Values with the same letter did not significantly differ at $\mathrm{P} \leq 0.05$ levels based on LSD test. 


\subsection{Proline content}

$\mathrm{NaCl}$ treatment had marked effects on proline content of barley plants (Figure 4E). As compared to control a significant enhanced in proline content was observed with increasing $\mathrm{NaCl}$ concentration. The Maximum improvement in proline content was recorded under $200 \mathrm{mM} \mathrm{NaCl}$ treatment (Figure 4E). An increase in proline content with MWCNTs treatment was noted in both stress and non-stress conditions (Figure 4E). MWCNTs at 500, 1000 and $2000 \mathrm{mg} \mathrm{kg}^{-1}$ enhanced proline content by about $12.96,11.65$ and $7.11 \%$ respectively under $200 \mathrm{mM} \mathrm{NaCl}$ (Figure 4E). Also, a significant increase in proline content was obtained in plants treated with $100 \mu \mathrm{m}$ SNP compared to the control plants, under $\mathrm{NaCl}$ levels (Figure 4F). Exogenous application of $\mathrm{NO}$ donor enhanced proline content by about 16.76 and $10.37 \%$ under 100 and $200 \mathrm{mM} \mathrm{NaCl}$ levels (Figure 4F). It was found that, application of SNP promoted the favorable effects of MWCNTs on proline content of barley (Table 2).

\subsection{MDA content}

A dose-dependent increase in MDA content was recorded in plants treated with $\mathrm{NaCl}$ as salinity stress agent (Table 1). The MWCNTs and SNP led to a reduction in MDA content under both stress and non-stress conditions. The reducing effect of MWCNTs and SNP was higher under salinity stress (Table 1). MDA content decreased significantly in the presence of MWCNTs with SNP. On the other word, employing SNP intensified the lowering effect of MWCNTs on MDA content (Table 1). MWCNTs (500 mg kg-1) plus SNP declined MDA content by about 36.31 and $33.56 \%$ respectively under 100 and $200 \mathrm{mM} \mathrm{NaCl}$ levels (Table 1).

\section{9. $\mathrm{H}_{2} \mathrm{O}_{2}$ content}

The $\mathrm{H}_{2} \mathrm{O}_{2}$ content was almost affected by $\mathrm{NaCl}$ concentrations and significant $(\mathrm{P} \leq 0.01)$ increase in $\mathrm{H}_{2} \mathrm{O}_{2}$ content was observed in barley leaves under salinity stress (Table 1). $\mathrm{NaCl}$ at 100 and $200 \mathrm{mM}$ enhance $\mathrm{H}_{2} \mathrm{O}_{2}$ content by about 39.35 and $63.13 \%$ over control. According to Table 1, MWCNTs and SNP dramatically affected $\mathrm{H}_{2} \mathrm{O}_{2}$ content of barley and the lowest $\mathrm{H}_{2} \mathrm{O}_{2}$ content was recorded from $500 \mathrm{mg} \mathrm{kg}^{-1}$ of MWCNTs with $100 \mu \mathrm{m}$ SNP. The combined treatments of MWCNTs (500 mg kg-1) and SNP reduced $\mathrm{H}_{2} \mathrm{O}_{2}$ content by about $22.7 \%$ respectively under 200 $\mathrm{mM} \mathrm{NaCl}$ (Table 1).

\subsection{0. $\mathrm{Na}^{+}$and $\mathrm{K}^{+}$contents}

$\mathrm{Na}^{+}$content significantly affected by exposure to salinity stress (Figure 5A and 5C). With the increase in $\mathrm{NaCl}$ concentration, remarkable enhancement in $\mathrm{Na}^{+}$ content was observed. However, with the further increase in $\mathrm{NaCl}$ concentration, considerable decreasing in $\mathrm{K}^{+}$content was noticed (Figure 5A and 5C). The data showed that at all levels of MWCNTs treatments, $\mathrm{Na}^{+}$accumulation in barley leaves declined in comparison with untreated plants.

As shown in Figure 5A, MWCNTs at $500 \mathrm{mg} \mathrm{kg}^{-1}$ diminished $\mathrm{Na}^{+}$content by 23.33 and $24.02 \%$ under 100 and $200 \mathrm{mM} \mathrm{NaCl}$. Additionally, in the presence of MWCNTs, $\mathrm{K}^{+}$content increased under salinity levels (Figure 5C). Exposing plants to SNP caused a significant reduction in $\mathrm{Na}^{+}$content (Figure 5B) and an increase in $\mathrm{K}^{+}$content of barley leaves under salt condition (Figure 5D). 
A

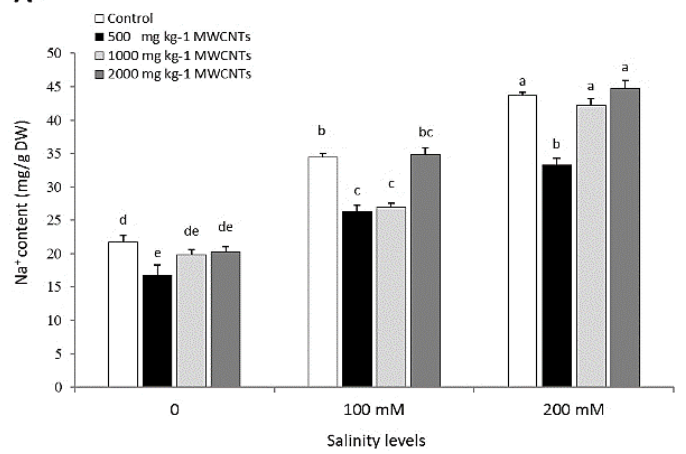

C

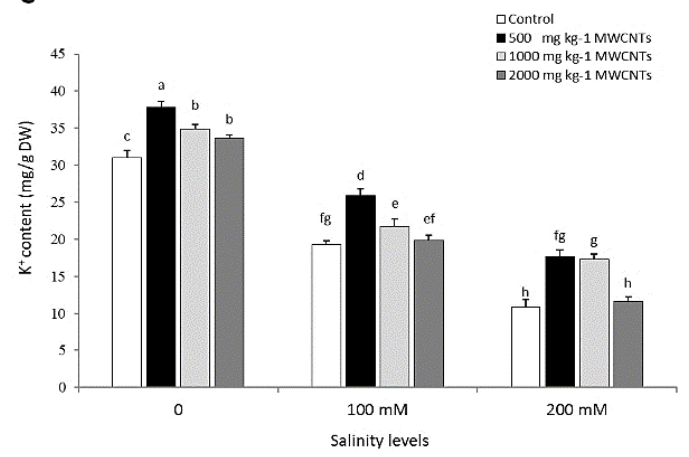

B

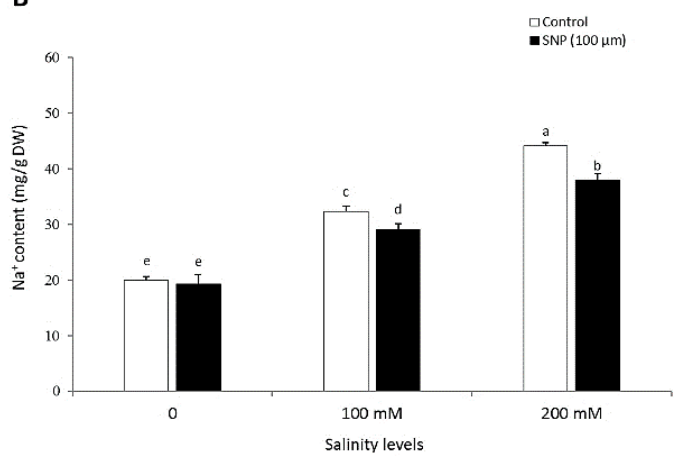

D

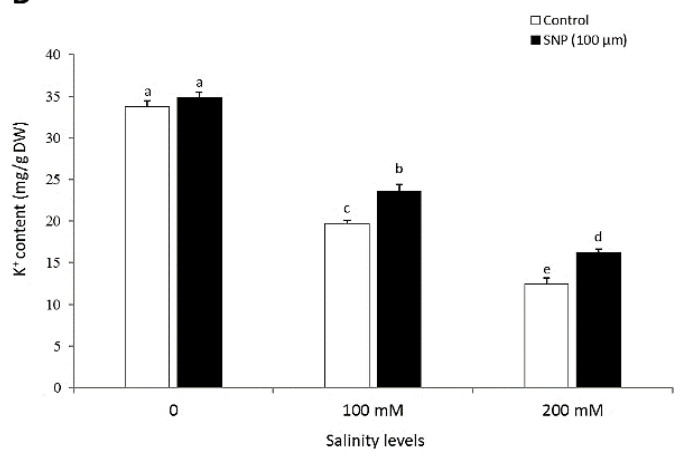

Figure 5. Effects of MWCNTs and salinity levels on $\mathrm{Na}^{+}(\mathrm{A})$ and $\mathrm{K}^{+}(\mathrm{C})$ content of barley. Effects of NO donor (SNP) and salinity levels on $\mathrm{Na}^{+}(\mathrm{B})$ and $\mathrm{K}^{+}$(D) content of barley. Values with the same letter did not significantly differ at $\mathrm{P} \leq 0.05$ levels based on LSD test.

\section{Discussion}

Results of our investigation showed that salt stress reduced the root and shoot lengths of barley plants. The deterrent impacts of salt stress on plants growth can be due to the accumulation of high amounts of toxic ions in various parts of plant, which leads to dehydration and eventually death of leaf cells and tissues. Growth reduction in stressed plants can occur because of inhibitory effects of salinity on photosynthesis, enzyme activity, nutrient homeostasis and over-production of ROS. In current study, evidence is provided that MWCNTs improved the growth of barley seedling in the both of salt-stressed and non-stressed conditions. Previous studies proved, MWCNTs after being aligned along and attached to the root surface or an inner portion of root, can enhance the growth of mesophyll cells and capillary action of water absorption, which leads to the faster growth in plants (Yuan et al., 2011). The stimulatory effects of MWCNTs on growth of barley may be due to improvement in root dehydrogenase activity, which in turn enhances the ability of water uptake of the plants. Our finding also showed that SNP application significantly promoted the barley root and shoot lengths under salinity stress. Foliar spray of SNP intensified the impacts of MWCNTs on barley shoot 
growth and increased plant tolerance to salt stress. Previously reported that, NO can increase membrane fluidness, induce cell enlargement and plant growth (Moro et al., 2017).

The reduction of RWC in leaves that resulted from $\mathrm{NaCl}$ stress may be related to high level of osmotic pressure under saline condition. Based on results, plants treated with MWCNTs had higher RWC compared to untreated plants. It seems that, MWCNTs can enhance RWC of barley plants mainly because of the stimulation of root lengths, roots dehydrogenase activity and subsequently promoting water uptake. It is acknowledged that, CNTs not only can act as molecular channels for water uptake (Liu et al., 2009) but also they are able to boost the water channel (aquaporins) gene expression and the activity of aquaporins under stressful condition (Khodakovskaya et al., 2012). In the present study, NO donor enhanced the RWC under salt stress. The favorable impacts of NO on the activity of vacuolar $\mathrm{H}^{+}$-ATPase and $\mathrm{H}^{+}$-PPase as proton pumps that provide the driving force for $\mathrm{Na}^{+} / \mathrm{H}^{+}$ exchange was previously reported in maize seedlings (Zhang et al., 2006).

The reduction in leaf chlorophyll concentration is a general phenomenon in plants subjected to salt stress. In this study, the total chlorophyll content was stimulated by MWCNTs or exogenous use of SNP under different levels of $\mathrm{NaCl}$. The degradation in chlorophyll may be attributed to the probable oxidation of chlorophyll under $\mathrm{NaCl}$ stress. MWCNTs can alleviate chlorophyll degradation by boosting barley antioxidant enzymes activities. Moreover, the higher water and minerals uptake in the presence of MWCNTs can lead to promoting the biosynthesis and formation of chlorophyll in barley plants. Beneficial impacts of MWCNTs on chlorophyll content of palm plants are reported by other researchers (Taha et al., 2016). In addition, the protective effect of SNP on leaf chlorophylls under salinity stress may be attributed to the mitigated oxidative damage induced by the $\mathrm{NaCl}$.
Photosynthesis is considered as one of the most sensitive physiological processes to environmental stresses. Our results revealed that, MWCNTs especially at 500 mg kg${ }^{-1}$ doses improved photosynthetic rate, stomatal conductance and transpiration rate of $\mathrm{NaCl}$-treated plants. MWCNTs promoted barley photosynthesis performance by enhancing water uptake, chlorophyll content and activity of antioxidant enzymes. It was proved earlier, CNTs are able to modify the chloroplast absorption profile and absorb light over a broad range of wavelengths in the ultraviolet, visible and near-infrared spectra that not captured by the chloroplast antenna pigments. The electronic band gap of semiconducting CNTs allows them to convert this absorbed solar energy into excitons that could transfer electrons to the photosynthetic machinery (Han et al., 2010). Giraldo et al. (2014) showed that CNTs passively transport and irreversibly localize within the lipid envelope of extracted plant chloroplasts, boost over three times higher photosynthetic activities. During the present investigation, foliar application of NO donor in the form of SNP increased the positive impacts of MWCNTs on photosynthetic rate of barley seedling and alleviated the adverse impacts of salinity on the photosynthetic parameters. Nitric oxide can alleviate the photosynthetic rate reduction by regulating non-stomatal factors under salinity stress (Fatma et al., 2016). In addition, the positive effect of SNP on barley photosynthesis is related to its role in diminishing chlorophyll degradation and promoting relative water content of plant. These results are in conformity with the findings of Farag et al. (2017) who also reported that NO can increase chlorophyll synthesis and decline chlorophyll degradation of plants.

The activities of antioxidant enzymes such as SOD, CAT and APX in barley plants enhanced under salt stress as well as in the presence of MWCNTs. It's well known that, salinity stress disturbs the cellular redox homeostasis and induces oxidative stress, which in 
turn, disturbs the balance between generation and removal of ROS. Among the antioxidant enzymes, SOD and CAT constitute a primary stage of defense. SOD catalyzes the dismutation of superoxide anions to hydrogen peroxide and oxygen, while CAT converts $\mathrm{H}_{2} \mathrm{O}_{2}$ into water and molecular oxygen. The plants treated with MWCNTs and SNP showed higher SOD activity under salinity stress. Notably, the combined treatment was more efficient than the sole application of MWCNTs or SNP. Similar trends were observed in APX and CAT responses to MWCNTs or SNP under $\mathrm{NaCl}$. Our findings are further supported by Ghorbanpour and Hadian (2015), who reported that, MWCNTs can be a novel tool to improve antioxidant compounds. It is assumed that, MWCNTs can act as signal compounds which result in promoting some physiological processes such as antioxidant enzymes activities. In the present investigation, activities of antioxidant enzymes of barley showed an increasing trend after foliar application of SNP under salt stress. NO may activate an antioxidant signaling pathway and play a protective role in plants against salinity stress. Similar results have been reported in cotton (Liu et al., 2014) where the exogenous application of SNP increased the antioxidant enzymes activities of plants.

It is widely acknowledged that, proline is one of the osmolytes responsible for maintaining cell turgor under stress condition. In our study, the barley stressed plants coped with cell dehydration by the accumulation of proline. Moreover, proline content of leaves stimulated by MWCNTs and exogenous SNP under $\mathrm{NaCl}$ concentrations. It is known that MWCNTs can promote proline synthesis, decrease its degradation and reduce the activity of proline dehydrogenase. Likewise, a changing in proline content with CNTs treatment was also reported in Hyoscyamus niger (Hatami et al., 2017) under stress condition. The induction of proline accumulation in response to NO may be due to an activation of proline synthesis through glutamate pathway (Fatma et al., 2016; Chen et al., 2015).

The reduction of total soluble proteins under stressful condition may be due to denaturation and irreversible damage to protein structure as a result of free radical invasions. In our study the TSP of barley leaves remarkably increased in plants treated with MWCNTs and NO donor. It's assumed, MWCNTs can decrease protein denaturation and degradation from ROS by activating plant antioxidant systems. The protective effects of CNTs on plants protein content have been reported previously (Hatami et al., 2017). Also, the positive effect of SNP may be attributed to its crucial role in contributing the better balance between carbon and nitrogen metabolism resulted in higher activity of endopeptidase and carboxypeptidase in plants under salt stress (Uchida et al., 2002).

$\mathrm{NaCl}$ stress indirectly induces the overproduction of different ROS, resulting in membrane lipid peroxidation and MDA production. We found that the amount of MDA decreased with MWCNTs and NO supply under salt stress. The results of present work indicate that the effect of MWCNTs in improving salt tolerance of barley is related to the alleviation of oxidative damage such as membrane lipid peroxidation and antioxidant enzymes. MWCNTs in the presence of SNP mitigated the adverse effect of salinity on cell membrane by reduction of lipid peroxidation at the cellular level. It is known that MWCNTs changes lipid composition, rigidity and permeability of the root plasma membranes under salinity condition (Martínez-Ballesta et al., 2016). Decreased MDA content in plants by exogenous NO was reported by other researchers (Liu et al., 2014). Therefore, it seems that MWCNTs and NO may play a physiological role in reduction of cell membrane injury by activating barley antioxidant enzymes and eliminating the over accumulation of ROS under salinity stress. 
$\mathrm{H}_{2} \mathrm{O}_{2}$ content followed the similar pattern with MDA in different concentrations of $\mathrm{NaCl}$. It's proved that, salinity stimulates the accumulation of the ROS such as $\mathrm{H}_{2} \mathrm{O}_{2}$ in plants cells. In our experiment, a significant reduction in $\mathrm{H}_{2} \mathrm{O}_{2}$ content was observed at salt-stressed plants treated with MWCNTs and SNP compared to the control. The metabolism of $\mathrm{H}_{2} \mathrm{O}_{2}$ is dependent on various functionally interrelated antioxidant enzymes such as CAT and POX. These enzymes are involved in the elimination of $\mathrm{H}_{2} \mathrm{O}_{2}$ from stressed cells. Hence, supplemental MWCNTs might decline $\mathrm{H} 2 \mathrm{O} 2$ content of barley by regulating antioxidant enzymes such as CAT and APX. The effective role of MWCNTs on $\mathrm{H}_{2} \mathrm{O}_{2}$ content under stressful condition was pointed out by other researchers (Hatami et al., 2017). In addition, the exogenous use of NO donor in the form of SNP alleviated the stimulating effect of $\mathrm{NaCl}$ stress on $\mathrm{H}_{2} \mathrm{O}_{2}$ production. It can be related to favorable impacts of $\mathrm{NO}$ on boosting antioxidant enzymes activating of barley.

In general, Higher $\mathrm{Na}^{+} / \mathrm{K}^{+}$ratios in plants under stress condition indicate metabolic disorders, such as a reduction of protein synthesis and enzyme activity, as well as an increase in membrane permeability. Under salinity stress, the $\mathrm{Na}^{+}$content of barley is negatively impressed by MWCNTs and NO donor. In contrast, barley's $\mathrm{K}^{+}$content enhanced in the MWCNTstreated plant. It is assumed that MWCNTs is able to modify the activity of plasma membrane H-ATPase and the balance between $\mathrm{Na}^{+}$and $\mathrm{K}^{+}$uptake in plant roots. Changing in plants $\mathrm{Na}^{+}$and $\mathrm{K}^{+}$content in the presence of MWCNTs have been reported previously (Tiwari et al., 2014). It was shown that, CNTs can facilitate the absorption or transportation of nutrients into plant tissues. However, some ions such as $\mathrm{Na}^{+}$ might be prevented from entering to plant cells by CNTs (Taha et al., 2016). One possible reason for the observed changing in the rate of $\mathrm{Na}^{+}$and $\mathrm{K}^{+}$could be the positive effect of $\mathrm{NO}$ on the expression of plasma membrane PM H $\mathrm{H}^{+}$-ATPase which is involved in $\mathrm{Na}^{+}$ and $\mathrm{K}^{+}$transportation (Chen et al., 2010).

\section{Conclusions}

The results of present experiment identify the role of MWCNTs (Multi-walled carbon nanotubes) and nitric oxide in reducing the uptake and accumulation of $\mathrm{NaCl}$ in barley seedling. It seems that the appropriate dosage of MWCNTs (500 mg kg-1) may prevent $\mathrm{Na}+$ accumulation and promote cell elongation in the root system with increase of water uptake in plants. The results indicated that MWCNTs as a growth regulator efficiently improved chlorophyll contents and photosynthesis parameters of barley under salinity stress. In addition, MWCNTs promoted the antioxidant enzyme activities such as superoxide dismutase, catalase and ascorbate peroxidase, which are able to improve the plants resistance against oxidative damage. Moreover, this study also revealed that foliar application of sodium nitroprusside could act as a modifier to alleviation of deleterious effects of salinity in barley. Exogenous sodium nitroprusside induced salt tolerance in barley seedling by decreasing the concentration of malonyldialdehyde and hydrogen peroxide that are likely associated with increases in antioxidant enzyme activities. Therefore, we suggest that nitric oxide donor in the form of sodium nitroprusside intensifies the beneficial impacts of MWCNTs on the growth of barley plants under salinity stress. However, those effects of sodium nitroprusside and MWCNTs in the NaCltreated plants may vary depending on the plant species. To confirm our findings, further research is required on other species. 


\section{Acknowledgements}

Financial support for this work was granted by the Department of Agronomy and plant Breeding, Faculty of agriculture, Bu-Ali Sina University, Hamadan, Iran.

\section{References}

Abdalla, S., Al-Marzouki, F., Al-Ghamdi, A.A., Abdel-Daiem, A. 2015. Different technical applications of carbon nanotubes. Nanoscale. Res. Lett. $10,1-10$.

Aebi, H. 1984. Catalase in vitro. Meth. Enzymol. 105, 121-126.

Arnon, I. 1975. Physiological principles of dryland crop production. Physiological Aspects of Dryland Farming. US Gupta, ed, 391 p.

Barrs, H., Weatherley, P. 1962. A re-examination of the relative turgidity technique for estimating water deficits in leaves. Aust. J. Biol. Sci. 15, 413-428.

Bates, L., Waldren, R., Teare, I. 1973. Rapid determination of free proline for water-stress studies. Plant Soil. 39, 205-207.

Bradford, M.M. 1976. A rapid and sensitive method for the quantitation of microgram quantities of protein utilizing the principle of protein-dye binding. Anal. Biohem. 72, 248-254.

Chen, J., Liu, X., Wang, C., Yin, S.S., Li, X.L., Hu, W.J., Simon, M., Shen, Z.J., Xiao, Q., Chu, C.C. 2015. Nitric oxide ameliorates zinc oxide nanoparticles-induced phytotoxicity in rice seedlings. J. Hazard. Mater. 297, 173-182.

Chen, J., Xiao, Q., Wu, F., Dong, X., He, J., Pei, Z., Zheng, H. 2010. Nitric oxide enhances salt secretion and $\mathrm{Na}^{+}$sequestration in a mangrove plant, Avicennia marina, through increasing the expression of $\mathrm{H}^{+}$-ATPase and $\mathrm{Na}^{+} / \mathrm{H}^{+}$antiporter under high salinity. Tree Physiol. 30, 1570-1585.
Dong, Y.J., Wang, Z.L., Zhang, J.W., Liu, S., He, Z.L., He, M.R. 2015. Interaction effects of nitric oxideand salicylic acid in alleviating salt stress of Gossypium hirsutum L. Soil Sci. Plant Nutr. 15, 561-573.

Enders, A., Lehmann, J. 2012. Comparison of wet-digestion and dry-ashing methods for total elemental analysis of biochar. Commun. Soil. Sci. Plant. 43, 1042-1052.

Farag, M., Najeeb, U., Yang, J., Hu, Z., Fang, Z.M. 2017. Nitric oxide protects carbon assimilation process of watermelon from boron-induced oxidative injury. Plant Physiol. Biochem. 111, 166173.

Fatma, M., Masood, A., Per, T.S., Rasheed, F., Khan, N.A. 2016. Interplay between nitric oxide and sulfur assimilation in salt tolerance in plants. Crop J. 4, 153-161.

Ghorbanpour, M., Hadian, J. 2015. Multi-walled carbon nanotubes stimulate callus induction, secondary metabolites biosynthesis and antioxidant capacity in medicinal plant Satureja khuzestanica grown in vitro. Carbon. 94, 749-759.

Giannopolitis, C.N., Ries, S.K. 1977. Superoxide dismutases I. Occurrence in higher plants. Plant Physiol. 59, 309-314.

Giraldo, J.P., Landry, M.P., Faltermeier, S.M., McNicholas, T.P., Iverson, N.M., Boghossian, A.A., Reuel, N.F., Hilmer, A.J., Sen, F., Brew, J.A. 2014. Plant nanobionics approach to augment photosynthesis and biochemical sensing. Nat. Mater. 13, 400-408.

Han, J.H., Paulus, G.L., Maruyama, R., Heller, D.A., Kim, W.J., Barone, P.W., Lee, C.Y., Choi, J.H., Ham, M.H., Song, C. 2010. Exciton antennas and concentrators from core-shell and corrugated carbon nanotube filaments of homogeneous composition. Nat. Mater. 9, 833-839. 
Hatami, M., Hadian, J., Ghorbanpour, M. 2017. Mechanisms underlying toxicity and stimulatory role of single-walled carbon nanotubes in $\mathrm{Hyo}$ scyamus niger during drought stress simulated by polyethylene glycol. J. Hazard. Mater. 324, 306320 .

Heath, R.L., Packer, L. 1968. Photoperoxidation in isolated chloroplasts: I. Kinetics and stoichiometry of fatty acid peroxidation. Arch. Biochem. Biophys. 125, 189-198.

Hussain, Z., Khattak, R.A., Irshad, M., Mahmood, Q., An, P. 2016. Effect of saline irrigation water on the leachability of salts, growth and chemical composition of wheat (Triticum aestivum L.) in saline-sodic soil supplemented with phosphorus and potassium. Soil Sci. Plant Nutr. 16, 604-620.

Khan, M.N., Mobin, M., Abbas, Z.K., AlMutairi, K.A., Siddiqui, Z.H. 2017. Role of nanomaterials in plants under challenging environments. Plant Physiol. Biochem. 110, 194-209.

Khodakovskaya, M.V., de Silva, K., Biris, A.S., Dervishi, E., Villagarcia, H. 2012. Carbon nanotubes induce growth enhancement of tobacco cells. ACS nano. 6, 2128-2135.

Liu, B., Li, X., Li, B., Xu, B., Zhao, Y. 2009. Carbon nanotube based artificial water channel protein: membrane perturbation and water transportation. Nano Lett. 9, 1386-1394.

Liu, S., Dong, Y., Xu, L., Kong, J. 2014. Effects of foliar applications of nitric oxide and salicylic acid on salt-induced changes in photosynthesis and antioxidative metabolism of cotton seedlings. Plant Growth Regul. 73, 67-78.

Loreto, F., Velikova, V. 2001. Isoprene produced by leaves protects the photosynthetic apparatus against ozone damage, quenches ozone products, and reduces lipid peroxidation of cellular membranes. Plant Physiol. 127, 1781-1787.
Martínez-Ballesta, M.C., Zapata, L., Chalbi, N., Carvajal, M. 2016. Multiwalled carbon nanotubes enter broccoli cells enhancing growth and water uptake of plants exposed to salinity. J. Nanobiotechnology. 14, 1-14.

Moro, C.F., Gaspar, M., Silva, F.R., Pattathil, S., Hahn, M.G., Salgado, I., Braga, M.R. 2017. S-nitrosoglutathione promotes cell wall remodelling, alters the transcriptional profile and induces root hair formation in the hairless root hair defective 6 (rhd6) mutant of Arabidopsis thaliana. New Phytol. $213,1771-1786$.

Nakano, Y., Asada, K. 1981. Hydrogen peroxide is scavenged by ascorbate-specific peroxidase in spinach chloroplasts. Plant Cell Physiol. 22, 867880 .

Singh, N.A. 2017. Nanotechnology innovations, industrial applications and patents. Environ. Chem. Lett. 15, 185-191.

Taha, R.A., Hassan, M.M., Ibrahim, E.A., Baker, N.H.A., Shaaban, E.A. 2016. Carbon nanotubes impact on date palm in vitro cultures. Plant Cell Tissue Organ Cult. 127, 525-534.

Tiwari, D., Dasgupta-Schubert, N., Cendejas, L.V., Villegas, J., Montoya, L.C., Garcia, S.B. 2014. Interfacing carbon nanotubes (CNT) with plants: enhancement of growth, water and ionic nutrient uptake in maize (Zea mays) and implications for nanoagriculture. Appl. Nanosci. 4, 577-591.

Torbaghan, M.E., Lakzian, A., Astaraei, A.R., Fotovat, A., Besharati, H. (2017). Salt and alkali stresses reduction in wheat by plant growth promoting haloalkaliphilic bacteria. J. Soil Sci. Plant Nutr. 17, 1058-1087.

Uchida, A., Jagendorf, A.T., Hibino, T., Takabe, T., Takabe, T. 2002. Effects of hydrogen peroxide and nitric oxide on both salt and heat stress tolerance in rice. Plant Sci. 163, 515-523. 
Yuan, H., Hu, S., Huang, P., Song, H., Wang, K., Ruan, J., He, R., Cui, D. 2011. Single walled carbon nanotubes exhibit dual-phase regulation to exposed Arabidopsis mesophyll cells. Nanoscale Res. Lett. 6, 1-9.
Zhang, Y., Wang, L., Liu, Y., Zhang, Q., Wei, Q., Zhang, W. 2006. Nitric oxide enhances salt tolerance in maize seedlings through increasing activities of proton-pump and $\mathrm{Na}^{+} / \mathrm{H}^{+}$antiport in the tonoplast. Planta. 224, 545-555. 